\title{
Research on the Influencing Factors of Bank Financial Ratio on Capital Structure
}

\author{
Lina Fathina \\ Magister Management, Perbanas Institute, Indonesia \\ linnafaa@gmail.com
}

\begin{abstract}
This study aims to see the effect of Return on Equity (ROE), Net Interest Margin (NIM), Operating Costs to Operating Income (BOPO), and Loan to Deposit Ratio (LDR) on the Capital Adequacy Ratio (CAR). The unit of analysis used in this study is PT Bank Danamon, Tbk for the period 2009 - 2016. The sample used in this study was taken from the Quarterly Financial Statements of PT Bank Danamon, Tbk for the period of 2009 the first quarter to 2016 the second quarter. The analytical tool used is multiple linear regression method and hypothesis testing. The results showed that the LDR variable had no significant effect on CAR with a significance level of 0.363, while the ROE, NIM, and BOPO variables had a significant effect on CAR with a significance level of 0.007; 0.003; and 0.046. Together the four variables contributed $34.3 \%$ to the CAR and the remaining $65.7 \%$ with other variables.
\end{abstract}

Keywords: Return on Equity (ROE), Net Interest Margin (NIM), Operating Costs to Operating Income (BOPO), and Loan to Deposit Ratio (LDR) to Capital Adequacy Ratio (CAR)

\section{Introduction}

The failure of a company can be seen and measured through financial statements by analyzing financial statements. Financial statement analysis is a very important tool to obtain information related to the company's financial position and the results that have been achieved in connection with the selection of the company's strategy to be implemented. By analyzing the company's financial statements, the company's leadership can find out the company's financial situation and development as well as the results that have been achieved in the past and in the current time.

The monetary crisis that began in mid - 1997, when the exchange rate of the rupiah depreciated against the US dollar, caused most companies to be unable to repay their loans to banks, while banks also faced the risk of not being able to pay their obligations, which were mostly financed by foreign loans and loans. public funds. The amount of credit reserves and losses as a result of the exchange rate difference causes a decrease in banking capital so that most banks are no longer able to fulfill their obligations to capital adequacy, the next result is a decline in banking performance which can be identified in the form of financial statement analysis using financial ratios, such as profitability ratios, liquidity ratios, solvency ratios, profitability ratios, and other financial ratios. Sugiyanto et al (2002) show that six financial ratios, namely Return On Equity (ROE), cost of funds ratio, Net Interest Margin (NIM), Loan to Deposit Ratio (LDR), interest income ratio in settlement to interest yield, and the ratio Operating Cost to Operating Income (BOPO) is able to predict the bankruptcy of a national bank in Indonesia (which is proxied through CAR) one year before it fails.

As of December 2015, the consolidated CAR (Minimum Capital Adequacy Requirement) ratio remained at the level of $19.67 \%$, up from the end of 2014. From the Bank's perspective alone, Danamon's CAR rose to $20.84 \%$ from $18.07 \%$ in December 2014. During the last 5 years, and for the financial year ended December 31, 2015, the CAR for banks alone and for consolidation was well above the minimum level required by BI of $9 \%-10 \%$.

\section{Posisi CAR PT Bank Danamon, Tbk}

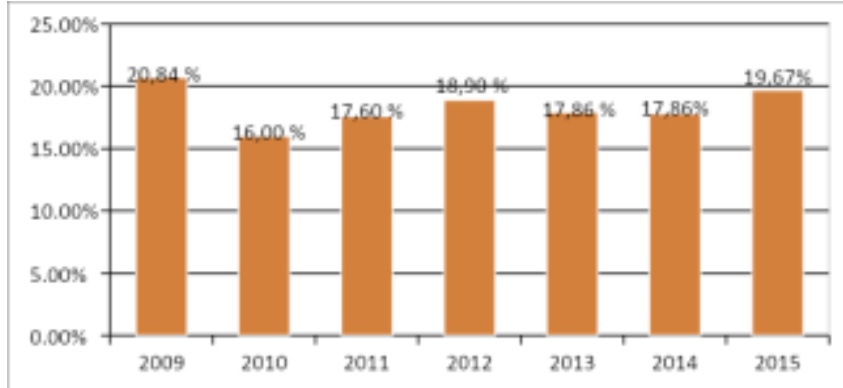

Sumber: LaporanTahunan PT Bank Danamon, Tbktahun 2015

\section{Theoretical Review}

Return on Equity (ROE) which is an indicator of the profitability ratio is used as an independent variable that affects CAR because according to Brigham and Gapenski (1997) companies with high investment returns will use small debt so that the level of capital costs that contain relatively small risks and the bank's own capital relatively high so as to increase CAR. Various studies have found that ROE has a significant positive effect on CAR (Shitawati, 2006; Fitrianto and Mawardi, 2006). However, research by Barus (2011) states that ROE has no significant effect on CAR. Meanwhile Andhini (2015) revealed that ROE has a negative and significant effect on CAR.

Net Interest Margin (NIM) is used as an independent variable that affects CAR because according to Muljono (1999) the higher the NIM indicates the more effective the bank is in placing earning assets in the form of credit. According to Arief (2014) that NIM has a significant positive effect on CAR, while according to Shitawati (2006) that NIM has a significant negative effect on CAR. It is also 
different from the results of Krisna's (2008) research that NIM has no significant positive effect on CAR.

Operational Cost to Operating Income (BOPO) is used as an independent variable that affects CAR because according to Muljono (1999) the smaller the BOPO indicates the more efficient the bank is in carrying out its business activities, because the operating costs that must be borne are smaller than the operating income so that the bank's operational activities generate profits. This is able to increase bank capital and minimize the level of risk, so that a relatively low BOPO can increase CAR. BOPO researched by Shitawati (2006) shows that there is a negative effect on CAR. In contrast to Krisna's (2008) research that BOPO has a positive and insignificant effect on CAR.

Loan to Deposit Ratio (LDR) is used as an independent variable that affects CAR because according to Muljono (1999) the higher the LDR indicates the riskier the bank's liquidity conditions, conversely the lower LDR indicates the bank's lack of effectiveness in lending, so the higher the LDR, the lower the CAR. liquidity conditions are threatened). LDR has a significant negative effect on CAR

Hasil Uji Normalitas

One-Sample Kolmogorov-Smirnov Test

\begin{tabular}{|ll|r|}
\hline & & \multicolumn{1}{|c|}{ CAR } \\
\hline Normal Parameters & Mean & 30 \\
& Std. Deviation & 18,0333 \\
& 1.80962 \\
Most Extreme & Absolute &, 174 \\
Differences & Positive & .174 \\
& Negative & -151 \\
Kolmogoros-Smimov Z &, 953 \\
Asymp. Sig. (2-tailed) & .324 \\
\hline
\end{tabular}

a. Test distribution is Normal

From the table, the Kolmogorov - Smirnov (K - S) is 0.953 and the significance is 0.324 , so it can be concluded that the data in the regression model is normally distributed, where the significance value is greater than $0.05(\mathrm{p}=0.324>0.05)$. In the normal plot graph, it can be seen that the points spread around the diagonal line and approach the diagonal line so that it can be concluded that the data in the regression model is normally distributed.

\section{2) Autocorrelation Test}

Hasil Uji Durbin-Watson Statistik

\begin{tabular}{|l|r|r|r|r|r|}
\hline \multicolumn{1}{|c|}{ Model Summary $^{b}$} \\
\hline Model & R & R Square & $\begin{array}{c}\text { Adjusted R } \\
\text { Square }\end{array}$ & $\begin{array}{c}\text { Std. Error of } \\
\text { the Estimate }\end{array}$ & $\begin{array}{c}\text { Durbin-Watso } \\
\text { n }\end{array}$ \\
\hline 1 & $.659^{\circ}$ & .434 & .343 & 1,46632 & 1,234 \\
\hline
\end{tabular}

a. Predictors: (Constant), LDR, NIM, BOPO, ROE

b. Dependent Variable: CAR

The Durbin - Watson value obtained from data processing is 1.234 and the value lies between -2 and +2 , so the which has been proven to be researched by Krisna (2008), Ftrianto and Mawardi (2006), and Arief (2014).

\section{Research Methods}

The analytical method used in this study is a quantitative method. Quantitative data analysis is a form of analysis that uses numbers and calculations using statistical methods, so that the data must be classified in certain categories using certain tables. The analytical tool used in this study is multiple regression analysis using the classical assumption test. To determine the accuracy of the model, it is necessary to test the basis of several classical assumptions of ordinary least squares (OLS), namely: normality, autocorrelation, heteroscedasticity, and multicollinearity tests. The regression model used is as follows.

CAR $=-2,561-0,323 R O E+0,841 N I M+0,142 B O P O$ $+0,06 L D R+e$

\section{Results and Findings}

\subsection{Analysis of research results}

\section{1) Normality Test}

Grafik Normal P - Plot

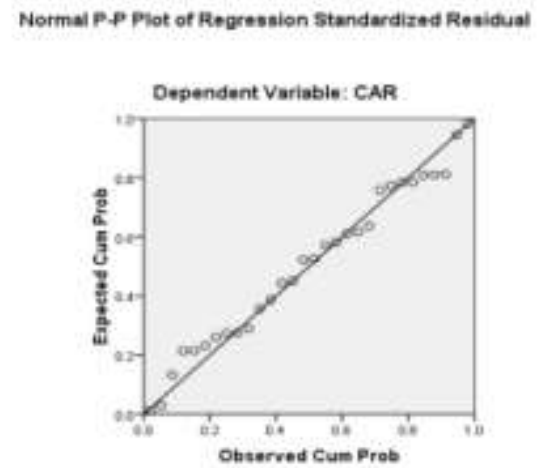

autocorrelation coefficient is equal to zero and it is concluded that there is no autocorrelation, so the regression model is feasible to use.

\section{3) Heteroscedasticity Test}

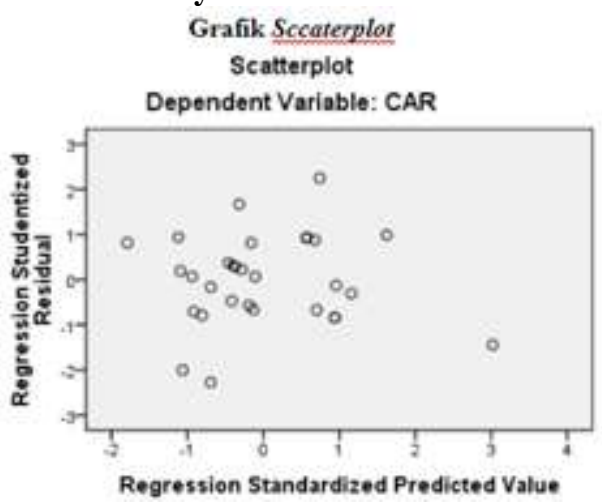

It can be seen that the points spread randomly and are spread both above and below the number 0 on the $\mathrm{Y}$ axis and do not spread and then narrow or vice versa above and below the number 0 on the $\mathrm{Y}$ axis so that it is stated that the regression 
model in this study occurs homoscedasticity or In other words, there is no heteroscedasticity.

\section{4) Multicollinearity Test}

Hasil $\mathrm{C}_{\mathrm{ji}}$ Multikolienaritas

\begin{tabular}{|c|c|c|}
\hline \multicolumn{3}{|c|}{ Coefficients" } \\
\hline \multirow{2}{*}{ Model } & \multicolumn{2}{|c|}{ Collinearity Statistics } \\
\cline { 2 - 3 } & Tolerance & VIF \\
\hline ROE &, 416 & 2,401 \\
NDM & 542 & 1,844 \\
BOPO & .603 & 1,657 \\
LDR & $\$ 27$ & 1,897 \\
\hline
\end{tabular}

able: CAR

It can be seen that the value of Variance Inflation Factor (VIF) of each variable is ROE 2.401; NIM 1, 844; BOPO 1, 657; and LDR 1.897, where this value illustrates that the VIF value of all independent variables is below 10 and the tolerance value is above 0.10 . This shows that there are no symptoms of multicollinearity.

\section{5) Multiple Linear Regression Test Results Hasil Cji Analisis Regresi Linear Berganda}

Coefficients'

\begin{tabular}{|c|c|c|c|c|c|c|c|}
\hline \multirow[b]{2}{*}{ Model } & \multicolumn{2}{|c|}{$\begin{array}{l}\text { Unstandardized } \\
\text { Coefficienss }\end{array}$} & \multirow{2}{*}{\begin{tabular}{c|}
$\begin{array}{c}\text { Standardized } \\
\text { Coefficients }\end{array}$ \\
Beta
\end{tabular}} & \multirow[b]{2}{*}{$\mathrm{t}$} & \multirow[b]{2}{*}{ Sig } & \multicolumn{2}{|c|}{$\begin{array}{l}\text { Collinearity } \\
\text { Staristics }\end{array}$} \\
\hline & B & Std Errot & & & & Tolerance & VIF \\
\hline (Conutant) & $-2,561$ & 10,372 & &,- 247 & 807 & & \\
\hline ROE & -323 & .111 & .680 & $-2,917$ & .007 & .416 & 2,401 \\
\hline NMM & .841 & .259 & .664 & 3,251 & .003 & .542 & 1,844 \\
\hline BOPO & .142 & .067 & .408 & 2,105 & .046 & .603 & 1,657 \\
\hline LDR & .060 & .064 & .192 & 927 & 363 & .527 & 1,897 \\
\hline
\end{tabular}

a. Dependent Variable: CAR

The constant of - 2.561 indicates that if the independent variable is assumed to have a value of 0 , then the capital adequacy ratio (CAR) is negative at -2.561 . It can be said that by assuming the absence of ROE, NIM, BOPO, and LDR variables, the Capital Adequacy Ratio (CAR) tends to decrease. ROE of - 0.323 indicates that every decrease in Return On Equity by 1 percentage, it will increase the Capital Adequacy Ratio (CAR) by 0.323 assuming other variables remain. The NIM of 0.841 indicates that every 1 percentage increase in Net Interest Margin will increase the Capital Adequacy Ratio (CAR) by 0.841 with the assumption that other variables are fixed. It can be said that by assuming the absence of other independent variables, if the NIM increases, the CAR tends to increase. BOPO of 0.142 indicates that each increase in operating income operating costs (BOPO) of 1 percentage, it will reduce the Capital Adequacy Ratio by 0.142 assuming other variables remain. LDR of 0.06 indicates that every increase in Loan To Deposit Ratio by 1 percentage, it will increase the Capital Adequacy Ratio by 0.06 assuming other variables remain. It can be said that by assuming the absence of other independent variables, if the LDR increases, then the Capital Adequacy Ratio (CAR) tends to increase.

\section{Conclusion}

Based on the research results, Return on Equity (ROE) has a significant negative effect on bank capital adequacy. A good bank, to always keep the ROE low, so that the CAR remains high even though the CAR has met the minimum capital requirement set by Bank Indonesia of $12 \%$. Furthermore, Net Interest Margin (NIM) has a positive effect on bank capital adequacy. Therefore, bank management needs to maintain loan interest rates and customer deposits to obtain optimal Net Interest Margin (NIM). Preferably in using operational costs, banks must reduce BOPO as optimally as possible, because it can have an impact on decreasing income which will lead to high CAR usage. Although LDR does not directly affect the capital adequacy of banks, banks should also pay attention to the level of LDR safe standards that have been set by Bank Indonesia. In allocating credit, banks should be more sensitive in looking at macroeconomic conditions and in allocating funds must take the right policies.

\section{References}

[1] Abdullah, Faisal. (2003). ManajemenPerbankan Teknik Analisis Kinerja Keuangan Bank. Malang: Universitas Muhammadiyah Malang Press.

[2] Algifari. (2000). AnalisisRegresi, Teori, Kasus\& Solusi. BPFE UGM, Yogyakarta.

[3] Almilia, Luciana Spica dan WinnyHerdiningtyas. (2005). Analisa Rasio Camel terhadapPrediksiKondisiBermasalah pada Lembaga PerbankanPeriode 2000 - 2002. JurnalAkuntansi dan Keuangan STIE Perbanas. Volume 7 Nomor 2.

[4] Altman, Edward I. . (1968). Financial Ratios: Discriminant Analyisis and The Prediction of Corporate Bankcruptcy. The Journal of Finance. Vol XXIII, pp.589 - 609. Arthur, A. T., \& A. J., S. (2003). Strategic management: concepts and cases. Boston: Mass McGraw - Hill/Irvin.

[5] Anjani, Dewa Ayu dan Purnawati, Ni Ketut. (2013). "Pengaruh Non Performing Loan (NPL), Likuiditas Dan Rentabilitas Terhadap Rasio Kecukupan Modal". Fakultas Ekonomi dan Bisnis Universitas Udayana. David, F. R., \& David, F. R. (2015). Manajemen Strategik. Jakarta: Salemba Empat.

[6] Arief, Elizar. (2014). Analisispengaruh NPL, NIM, BOPO, dan LDR terhadap Capital Adequacy Ratio (StudiEmpiris: Bank Umum di Indonesia Periode 2008 - 2012). Skripsi. Makasar: Program StudiManajemen Universitas Hasanuddin.

[7] Arief, Sritua. (2006). MetodologiPenelitanEkonomi. Jakarta: Penerbit Universitas Indonesia. Hasibuan, Malayu. SP. (2008). Dasar - dasarPerbankan. Jakarta: BumiAksara.

[8] Ariefianto, Moch. Doddy. (2012). EkonometrikaEsensi dan AplikasidenganMengunakanEviews. Jakarta: PenerbitErlangga.

[9] Barus, Andreani Caroline. (2011). AnalisisProfitabilitas dan LikuiditasTerhadap Capital Adequacy Ratio Pada InstitusiPerbankan Terbuka di Bursa Efek Indonesia. JurnalWiraEkonomiMikroskil. Volume 1, Nomor 01. 
[10] Beaver, William H. . (1966). Financial Ratio as Predictors of Failure. Journal of Accounting Research.

[11] Brigham, E. F. dan Gapenski, L. C. . (1997). Intermediate Financial Management, Fifth Edition International Edition. The Dryden Press.

[12] Dambolena, Ismail G., dan Khoury. (1980). Ratio Stability and Corporate Failure. The Journal of Finance. Vol XXX, pp.1017 - 1027.

[13] Dendawijaya, Lukman. (2009). ManajemenPerbankan. EdisiPertama. Jakarta: Ghalia Indonesia.

[14] Ghozali, Imam. (2005). AplikasiAnalisis Multivariate dengan program SPSS. Badan Penerbit Universitas Diponegoro, Semarang.

[15] Ghozali, Imam. (2006). AplikasiAnalisisMultivariatDengan Program (SPSS.16). Gramedia

[16] Ghozali, Imam. (2011). AplikasiAnalisis Multivariate Dengan Program IBM SPSS 19. Semarang: Badan Penerbit Universitas Diponegoro.

[17] Harahap, SofyanSyafri. (2013). AnalisisKitisatas LAPORAN KEUANGAN. Cetakan ke - 11. Jakarta: PT. RajaGrafindoPersada.

[18] Hery\&HernaSelvia. AnalisiskinerjaManajemen. Jakarta: Grasindo.

[19] Hutahuruk (Ed.). (1991). Dasar dasarManajemenKeuangan. Jakarta: Erlangga.

[20] Indira Januarti. (2002). VariabelProksi CAMEL dan Karakteristik

Bank LainnyaUntukMemprediksiKebangkrutan Bank di Indonesia. JurnalBisnis Strategi. Vol.10, Desember, hal.1 - 26.

[21] Janie, Dyah Nirmala Arum. (2012). StatistikDeskriptif Dan Regresi Linear BergandaDengan SPSS. Semarang: Semarang University Press.

[22] Kasmir. (1998). Bank dan Lembaga KeuanganLainnya. Jakarta: Raja GrafindoPersada.

[23] Kasmir. (2007). ManajemenPerbankan. Jakarta: Raja GrafindoPersada.

[24] Kasmir. (2010). Dasar - Dasar Perbankan. EdisiRevisi 2010. Jakarta: Rajawali pers

[25] Kasmir. (2012). ManajemenPerbankan. Jakarta: Raja GrafindoPersada.

[26] Krisna, Yansen. (2008). Faktor - faktor yang Mempengaruhi Capital Adequacy Ratio (Studi pada Bank - Bank Umum di Indonesia periode 2003 - 3006). Tesis. Semarang: Program Studi Magister Manajemen Universitas Diponegoro.

[27] Leon, Boy \& Ericson, Sonny. (2008). ManajemenAktivaPasiva Bank Devisa. Jakarta: PT. Grasindo.

[28] Mahardian, Pandu. (2008). AnalisisPengaruhRasio CAR, BOPO, NPL, NIM, dan LDR Terhadap Kinerja KeuanganPerbankan. Tesis. Semarang: Program Studi Magister Manajemen Universitas Diponegoro.

[29] Muljono, TeguhPudjo.

"AnalisaLaporanKeuanganUntukPerbankan".

(1999).

EdisiRevisi 1999, Cetakan 6. Jakarta Djambtan.

[30] Mulyaningrum, Penny. (2008). PengaruhRasioKeuanganTerhadapKebangkrutan Bank di Indonesia. Tesis. Semarang: Program Studi Magister Manajemen Universitas Diponegoro.

[31] Mulyati, Tatik. (2001). Peran Financial Leverage TerhadapProfitabilitasdalamSektorPerbankan
Indonesia. JurnalEkonomi dan Manajemen. Vol.2, No.1, Juni, hal.55 - 65.

[32] Natasia, Rizky. (2015). PengaruhRisikoKredit, Profitabilitas, Likuiditas, dan Efisiensi Usaha TerhadapKecukupan Modal Pada Bank Yang Terdaftar Di Bursa Efek Indonesia Periode 2010 - 2014. E Journal. Surabaya: Universitas Negeri Surabaya.

[33] Peraturan Bank Indonesia nomor: 15/12/PBI/2013

[34] Peraturan Bank Indonesia nomor: 17/11/PBI/2015

[35] Rivai, Veithzal. et al. (2012). ManajemenPerbankandariTeorikePraktik. Depok: PT Raja GrafindoPersada.

[36] Riyadi, Selamet. (2006). Banking Assets and Liability Management. Jakarta: FakultasEkonomi Universitas Indonesia.

[37] Robert, Ang. (1997). BukuPintar: Pasar Modal Indonesia (The Intelligent Guide to Indonesian Capital Market). Mediasoft Indonesia

[38] Samsul H. Pasaribu dan Romi M. Hasiholan. (2001). PengaruhPaketRegulasiPerbankan 1998 TerhadapKehati - hatianSektorPerbankan di Indonesia: AnalisisTerhadap Capital Adequacy Ratio (CAR). TelaahBisnis. Vol.2, No.2, hal.83 - 97.

[39] Santoso, Singgih. (1999). SPSS (Statistical Produst and Service Solutions). Jakarta: PT Elex Media komputindo.

[40] Shingjergji, Ali dan Hyseni, Marsida. (2015). The Determinants of The Capital Adequacy Ratio In The Albanian Banking System During 2007 - 2014. International Journal of Economics, Commerce and Management. Vol.3, No.1.

[41] Shitawati, Artin. (2006). AnalisisFaktor - faktor yang berpengaruhterhadap Capital Adequacy Ratio (StudiEmpiris: Bank Umum di Indonesia Periode 2001 - 2004). Tesis. Semarang: Program Studi Magister Manajemen Universitas Diponegoro.

[42] Soegoto, Eddy Soeryanto. (2008). Marketing Research. Jakarta: PT. Elex Media Komputindo.

[43] Sugiyanto, dkk. (2002). ManfaatIndikator IndikatorKeuanganDalamPembentukan Model PrediksiKondisi Kesehatan Perbankan. JurnalBisnis Strategi. Vol.10, hal.11 - 23.

[44] Sulaiman, Wahid.2004. AnalisisRegresiMenggunakan SPSS, ContohKasus dan Pemecahannya. Yogyakarta: Andi

[45] Taswan. (2008). ManajemenPerbankan. Yogyakarta: UPP STIM YKPN.

[46] Umar, Husein. (2010). MetodologiPenelitian. Bandung: Alfabeta Bandung.

[47] Wahyono, Teguh. (2006). Analisis Data StatistikDengan SPSS 14. Jakarta: PT. Elex Media Komputindo.

[48] Weston, J. Fred; Thomas E. Copeland. (1999). ManajemenKeuangan, EdisiKesembilan, Jilid 2. Jakarta: BinarupaAksara.

[49] Yuliani, Desak Nyoman Sri Werasturi, Edy Sujana. (2015). Pengaruh Loan To Deposit Ratio (LDR), Non Performing Loan (NPL), Return On Assets (ROA), Dan BiayaOperasionalPendapatanOperasional. E Journal Akuntansi. Volume 3 No 1. 